\section{Physical and mechanical characteristics of poor-quality wood after heat treatment}

\author{
Manuela Romagnoli (1), Daniela Cavalli ${ }^{(2)}$, Rinaldo Pernarella ${ }^{(3)}$, Roberto \\ Zanuttini $^{(4)}$, Marco Togni ${ }^{(5)}$
}

Poor-quality Corsican pine (Pinus nigra subsp. laricio (Poir.) Maire) and Douglas fir (Pseudotsuga menziesii (Mirb.) Franco) wood samples were heat treated with the aim of testing the improvement of wood quality that could increase their economic value. Wood properties were measured to assess quality in treated and non-treated materials, including density, hardness, anti-swelling efficiency $(A S E)$, modulus of elasticity $(M O E)$, modulus of rupture (MOR), and compression strength. The results showed higher dimensional stability in heattreated wood, yet mechanical performance in compression and bending strength were only marginally affected by loss of density. Despite having a relatively low density after heat treatment, Corsican pine sapwood has potential in manufacturing higher-value products. In contrast, heat treatment applied to Douglas fir wood did not appear economically viable; insufficient differences were detected between the naturally desirable characteristics of this species and heat-treated samples.

Keywords: Thermowood, Density, Compressive Strength, Bending Strength, Sapwood, Wood Quality, Douglas Fir, Corsican Pine

\section{Introduction}

High-temperature heat treatment is considered a suitable method to improve wood characteristics. It reduces toxic chemical applications normally required to increase wood durability (Kandem et al. 2002, Welzbacher \& Rapper 2007, Mohareb et al. 2010) and enhance dimensional stability, reducing the hygroscopic behavior of the material (Kortelainen et al. 2006). High-temperature treatment can be viewed as a type of wood modification, due to the possibility of controlling color changes (Bekhta \& Niemz 2003, Johanson \& Moren 2006, Esteves et al. 2007a, 2008) and mechanical performance (Bekhta \& Niemz 2003, Welzbacher et al. 2007, Bal 2014). The process results in a new material in terms of durability, woodwater relationships and some mechanical properties, which exhibits performance dependent on the specific high-temperature treatment conditions (Militz 2002, 2008, Esteves \& Pereira 2008), but the wood product does not present any environmental hazards in its disposal (Hillis 2006). The final product typically has the disadvantage of reduced mass and mechanical performance, although some difference in degree of change has been observed between softwoods and hardwoods depending on the treatment method (Kocaefe et al. 2010, Li et al. 2011).

Therefore, the overall extent of modification and the final result of the process is quite variable. In this study, we assessed heat treatment effects on Corsican pine and Douglas fir wood properties obtained from a conifer reforestation site in Italy, with particular consideration of different sapwood and heartwood behavior. This timber is considered poor quality and is currently used as biomass for energy or packaging.

\section{Materials and methods}

\section{Study area}

Forty Douglas fir (Pseudotsuga menziesii)

(1) DAFNE, University of Tuscia, Viterbo (Italy); (2) DIBAF, University of Tuscia, Viterbo (Italy); (3) Margaritelli Farm, Perugia (Italy); (4) Agroselviter, Torino University (Italy); (5) GEESAF, Firenze University (Italy)

@ Manuela Romagnoli (mroma@unitus.it)

Received: Dec 31, 2013 - Accepted: Sep 23, 2014 - Final Acceptance: 01 Apr 2015

Citation: Romagnoli M, Cavalli D, Pernarella R, Zanuttini R, Togni M, 2015. Physical and mechanical characteristics of poor-quality wood after heat treatment. iForest 8: 884-891 [online 2015-05-22] URL: http://www.sisef.it/iforest/contents/?id=ifor1229-007

Communicated by: Giacomo Goli

and 40 Corsican Pine (Pinus nigra ssp. laricio) trees were sampled in an artificial mixed stand in Poggio Nibbio near Viterbo, Central Italy (latitude $42^{\circ} 22^{\prime} \mathrm{N}$, longitude $12^{\circ} 10^{\prime}$ W). Trees were arranged in rows with a cross-distance of $4 \mathrm{~m}$; the stand was thinned to promote tree regeneration and introduction of indigenous hardwoods. The harvested wood is generally of poor quality due to the fact that the trees have grown quite fast, and not straight, producing large rings that contain a high proportion of earlywood. The sapwood is also quite large, particularly in Corsican pine.

From each of the eighty trees sampled, single boards $6 \mathrm{~cm}$ thick, $80 \mathrm{~cm}$ long, and $7 \mathrm{~cm}$ in width were produced and subsequently crosscut to obtain two half-boards of approximately $40 \mathrm{~cm}$ in length. From these two half boards, we obtained twin specimens measuring $2 \times 2 \mathrm{~cm}$ in the transverse radial and tangential directions, and $40 \mathrm{~cm}$ longitudinally. The wood samples were largely juvenile, approximately 10 years in cambial age, and evidence of reaction wood was not observed in any samples analyzed. For each of the $2 \times 2 \times 40 \mathrm{~cm}$ sample pairs, one sample was heat treated, and the second sample was left untreated. Subsequently, two blocks measuring $2 \times 2 \times 3 \mathrm{~cm}$ in size were cut from the end of each sample to measure post-treatment/treated ( $\mathrm{t}$ ) and control sample/ not treated (nt) physical properties and compression strength; the total sample size was 160 specimens. Only sapwood samples were used in Corsican pine (CP), as the heartwood was limited to a very narrow inner portion of the sample section. However, the heartwood occupied a much larger surface area and increased number of rings in Douglas fir; therefore it was possible to distinguish and discuss the results for sapwood (D-S) and heartwood (D-H) samples separately.

\section{Heat treatment}

Thermowood treatment was performed at the Margaritelli farm in France (http://www. margaritelli.com/france) according to the following steps:

- Preliminary heating stage at $110^{\circ} \mathrm{C}$.

- Drying phase. The wood was fully dried to prepare it for high-temperature treatment by a gradual warming over $14 \mathrm{~h}$ until a temperature of $140{ }^{\circ} \mathrm{C}$ was reached. An atmosphere of superheated steam, with low oxygen content, prevented the formation of cracks and alterations within the wood. At the end of this phase, wood moisture content was reduced to little more than $0 \%$.

- High-temperature treatment phase. Application of $210^{\circ} \mathrm{C}$ for $2 \mathrm{~h}$.

- Cooling phase. Following the heat treatment, the cooling phase slowly reduced the wood temperature to $80-90{ }^{\circ} \mathrm{C}$ over the course of 15-20 h, allowing for moisture 
adsorption. The wood typically measured equilibrium moisture content between 3$4 \%$ at the end of this treatment.

\section{Physical parameters}

Untreated samples in fresh state were conditioned in the laboratory at $20{ }^{\circ} \mathrm{C}$ and $65 \%$ relative humidity $(\mathrm{RH})$, reaching an equilibrium moisture content (EMC) of $12 \%$. Half of the samples were then subjected to heattreatment; after the treatment the heat-treated samples showed a moisture content between 8 and $11 \%$. Density of samples was measured and their values were subsequently adjusted in treated samples to $12 \%\left(\rho_{12}\right)$ using the UNI-ISO-1361 formula for moisture content correction (eqn. 1):

$$
\rho_{12}=\rho_{w} \cdot\left[1-\frac{(1-K)(W-12)}{100}\right]
$$

where $W$ is the wood moisture measured as $W=\left[\left(m_{\mathrm{w}}-m_{\mathrm{o}}\right) / m_{\mathrm{o}}\right] \cdot 100, m_{\mathrm{w}}$ is the fresh weight, $m_{0}$ is the dry weight $(0 \%$ moisture content), and $K$ is the coefficient of volumetric shrinkage, assumed to be $K=0.85$ $\rho_{\mathrm{w}}$. We adopted the above procedure to compare all the physical and mechanical properties of treated samples with the untreated ones at the same moisture content.

Following EMC measurements, all samples (both treated and untreated) were soaked in water until a constant weight was reached, which was considered the maximum water content, and sample linear size and volume were measured again. The samples were subsequently placed in a $103{ }^{\circ} \mathrm{C}$ oven until achieving a constant weight and dry state.

a
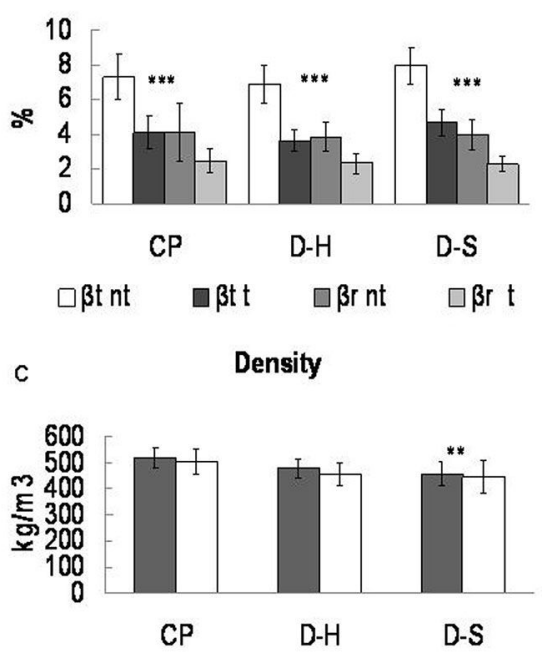

$\square \mathrm{nt}$

$\square \mathbf{t}$

Fig. 1 - Physical characteristics of treated $(\mathrm{t})$ and untreated (nt) Corsican pine (CP), Douglas fir heartwood (D-H), and Douglas fir sapwood (D-S). (a) Tangential shrinkage $\left(\beta_{\mathrm{t}}\right)$ and radial shrinkage $\left(\beta_{\mathrm{r}}\right)$; (b) anisotropy coefficient; (c) density; and (d) basic density. $(*),(* *),(* * *)$ : levels of significance between treated $(\mathrm{t})$ and untreated $(\mathrm{nt})$ specimens at $\mathrm{P}<0.05, \mathrm{P}<0.01$, and $\mathrm{P}<0.001$, respectively using the Bonferroni test. Vertical bars represent standard error.

\section{Mechanical properties}

Three samples of each species, taken from 40 specimens of each taxon (totalling 240 samples, 120 Corsican pine and 120 Douglas fir), were tested to measure main mechanical properties, and differences between treated and untreated wood.

All test samples were prepared by cutting pieces from the remaining wood strips; and all mechanical tests were performed using a Zwick-Roell universal testing machine.

Three mechanical tests (Romagnoli \& Spina 2013) were performed to evaluate the following:

- Compression strength in the longitudinal direction, using specimens $2 \times 2 \times 3 \mathrm{~cm}$ in accordance with UNI-ISO-3787 (1985).

- Modulus of elasticity (MOE), using a three-point bending test with a preload of $50 \mathrm{~N}$ and a machine head speed of 8 $\mathrm{mm} / \mathrm{min}$. The distance between the support points was $28 \mathrm{~cm}$, and the load was applied in a tangential direction at a point 14 $\mathrm{cm}$ from the supports.

- Modulus of rupture (MOR) during bending of $2 \times 2 \times 32 \mathrm{~cm}$ specimens, as per UNI-ISO-13061-3.

- Hardness (Brinell hardness, HB) according to UNI-EN-1534 (2011), which was carried out using a preload of $50 \mathrm{~N}$ and a test speed of $15 \mathrm{~mm} / \mathrm{min}$. All samples were tested tangentially and measured $30 \times 20 \times$ $20 \mathrm{~mm}$ in size.

The treated sample moisture content $(\approx 8 \%)$ was below the reference condition, and thus the measured value was adjusted to $12 \%$ moisture by adopting the formula provided by the UNI-ISO-3787 (1985) standards (eqn. $3)$ :

$$
P_{\max }=1+\left[0.02\left(M C_{t}-12\right)\right]
$$
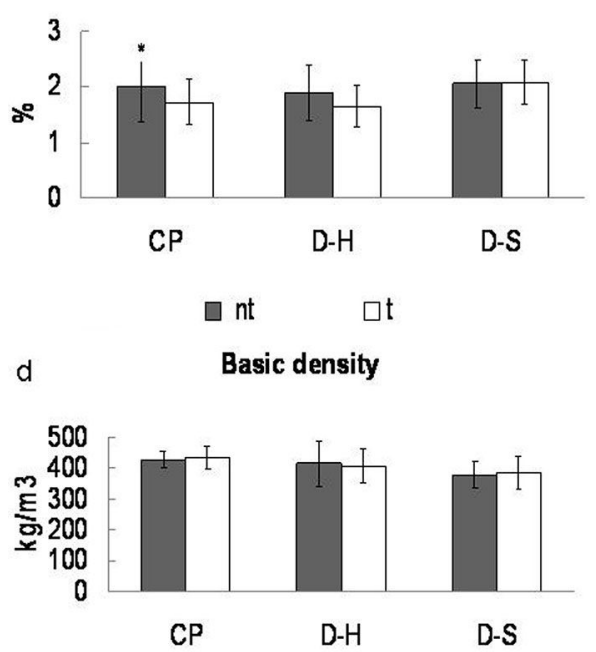

where $P_{\max }$ is the maximum load and $M C_{\mathrm{t}}$ is the moisture content of treated specimen.

\section{Statistical analysis}

Pairwise differences in physical and mechanical properties of wood samples were tested by two-sample Kolmogorov-Smirnov test $(\alpha=0.05)$. Pearson's correlation coefficients were calculated to assess the relationships between density and physical and mechanical properties of treated and nontreated wood. The relationships between density and other wood properties were further investigated by linear regression analysis.

\section{Results and discussion}

The non-treated wood of the Corsican pine and Douglas fir obtained from the Poggio Nibbio site had specific densities (Fig. 1c) that fall within the lower threshold for the two species $\left(467 \mathrm{~kg} \mathrm{~m}^{-3}\right.$ for Douglas fir and $517 \mathrm{~kg} \mathrm{~m}^{-3}$ for Corsican pine - Nardi Berti 2006), and are even low compared with 
other sites in Italy (Fioravanti 1999, Todaro \& Macchioni 2011).

Results showed the mechanical properties of non-treated Corsican pine wood (45 MPA for compression strength - Fig. 2a-d, Tab. 1) were comparable to previously published values (Nardi Berti 2006, Fioravanti 1999, Lachenbruch et al. 2010), except for MOE which was lower. Douglas fir sapwood showed lower density values compared to heartwood (Fig. 1c), but the mechanical properties revealed little difference between the two wood portions (Fig. 2a-d, Tab. 1). However, sapwood shrinkage (Fig. 1a) was higher than heartwood, which was similarly reported by Metsä-Kortelainen (2011).

The most important heat treatment outcome was an increased dimensional stability. In addition, a significant $(\mathrm{P}<0.001)$ decrease in shrinkage values (approximately $42 \%$ in Douglas fir and $40 \%$ in Corsican pine) were observed, as compared with non-treated wood (Fig. 1a).

Wood modification significantly $(\mathrm{P}<0.05)$ reduced the anisotropy coefficient in Corsican pine ( $\approx 14 \%$ - Fig. $1 b)$. Results showed a $12 \%$ change in Douglas fir heartwood, though not statistically significant. Militz (2002) reported similar results for stone pine.

Heat treatment effects were reflected by an $A S E$ value of $44 \%$ (Fig. 3) for Douglas fir and Corsican Pine, which exceeded values reported for hardwoods, including eucalyptus (24\% - Santos 2000) and silver oak $(<40 \%$ - Srinivas \& Pandey 2012), and some tropical species (9.2-14.8\% - Korkut 2012). These values were considerably lower compared to Chinese fir (Cunninghamia lanceolata , $>60 \%$ - Cao et al. 2012). Moreover, the $A S E$ value in Douglas fir was comparable to the volume swelling obtained by $\mathrm{Li}$ et al. (2011).

Results showed increased $A S E$ values in the tangential direction for Corsican pine and Douglas fir heartwood samples, consistent with P. banksiana (Poncsak et al. 2011), $P$. sylvestris and $P$. radiata (Militz 2002). However, despite substantial stability improvement in the tangential direction, the anisotropy coefficient (Fig. 1b) remained quite high in heat-treated specimens, congruent with results observed by Esteves et al. (2007a, 2007b, 2008). This minor effect of the treatment in the radial direction might be due to the higher lignin content, which is less sensitive to heat (González-Peña et al. 2009).

Heat treatment did not significantly affect specific density in Douglas fir and Corsican pine. A marked reduction in specific density of heat-modified wood was previously detected in hardwoods (Welzbacher \& Rapper 2007, Korkut 2012) and conifers, including P. elliottii (Severo et al. 2012), P. sylvestris and Picea abies (Boonstra et al. 2007). A a

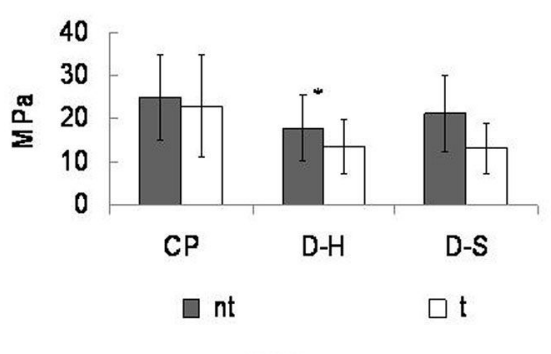

c

MOR

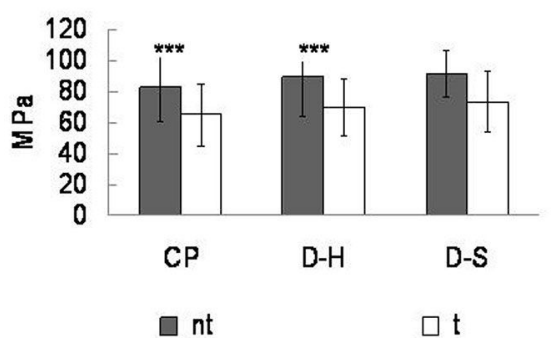

b

Compression strength

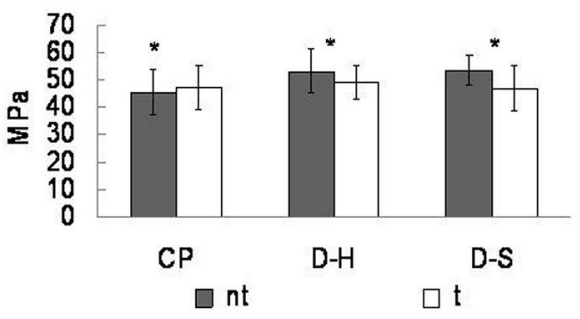

d

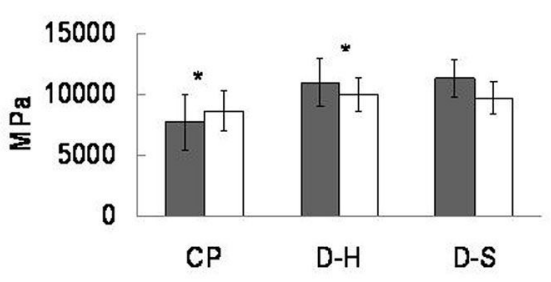

nt

$\square \mathrm{t}$

Fig. 2 - Mechanical properties of treated ( $t$ ) and untreated (nt) specimens of Corsican pine (CP), Douglas fir heartwood (D-H) and Douglas fir sapwood (D-S): (a) Brinell test; (b) Compression strength; (c) MOR (modulus of rupture to bending stress); (d) MOE (static bending modulus of elasticity). $(*),(* *),(* * *)$ : levels of significance between treated $(\mathrm{t})$ and untreated (nt) specimens at $\mathrm{P}<0.05, \mathrm{P}<0.01$, and $\mathrm{P}<0.001$, respectively using the Bonferroni test. Vertical bars represent standard error.

Tab. 1 - Descriptive statistics. (t): treated specimens; (nt): untreated specimens; (MOR): modulus of rupture to bending stress; (MOE): static bending modulus of elasticity; (SD): standard deviation; (n): sample size.

\begin{tabular}{|c|c|c|c|c|c|c|c|c|c|}
\hline \multirow{2}{*}{$\begin{array}{l}\text { Wood } \\
\text { type }\end{array}$} & \multirow[t]{2}{*}{ Stats } & \multicolumn{2}{|c|}{$\begin{array}{l}\text { Compression } \\
\text { strength }\left(\sigma_{12}\right)\end{array}$} & \multicolumn{2}{|c|}{ MOR } & \multicolumn{2}{|c|}{ MOE } & \multicolumn{2}{|c|}{$\begin{array}{c}\text { Brinell test } \\
\text { (HB) }\end{array}$} \\
\hline & & nt & $\mathbf{t}$ & nt & $\mathbf{t}$ & nt & $\mathbf{t}$ & nt & $\mathbf{t}$ \\
\hline Douglas fir & mean & 53.17 & 49.11 & 89.16 & 69.73 & 10955.71 & 9976.07 & 17.78 & 13.55 \\
\hline \multirow[t]{2}{*}{ Heartwood } & SD & 7.82 & 5.92 & 25.39 & 18.23 & 1979.11 & 1381.77 & 7.58 & 6.16 \\
\hline & $\mathrm{n}$ & 28 & 28 & 28 & 28 & 28 & 28 & 28 & 28 \\
\hline Douglas fir & mean & 53.53 & 46.84 & 91.46 & 73.09 & 11279.17 & 9680.00 & 21.13 & 13.17 \\
\hline \multirow[t]{2}{*}{ Sapwood } & SD & 5.54 & 8.36 & 14.96 & 19.79 & 1525.39 & 1319.32 & 8.77 & 5.78 \\
\hline & $\mathrm{n}$ & 12 & 12 & 12 & 12 & 12 & 12 & 12 & 12 \\
\hline Corsic & mean & 45.52 & 47.16 & 82.43 & 64.83 & 7723.33 & 8628.46 & 24.95 & 23.00 \\
\hline \multirow[t]{2}{*}{ Pine } & SD & 8.28 & 7.80 & 21.94 & 20.12 & 2259.01 & 1625.38 & 9.91 & 11.83 \\
\hline & $\mathrm{n}$ & 40 & 40 & 40 & 40 & 40 & 40 & 40 & 40 \\
\hline
\end{tabular}

lower reduction in treated wood specific density, comparable to our experimental results, was observed in P. sylvestris (Zaman et al. 2000).

Following heat treatments, we observed a general decrease in mechanical performance in Douglas fir sapwood and heartwood. This result is consistent with most conifers treated

at approximately $200{ }^{\circ} \mathrm{C}$ (Bengtsson et al. 2002, Esteves \& Pereira 2008, Bakar et al. $2013)$ or higher $\left(280^{\circ} \mathrm{C}-\mathrm{Stamm}\right.$ et al. 1946 , Esteves \& Pereira 2008). We also observed a reduction in Brinell hardness previously detected in spruce, beech, and red oak (Bakar et al. 2013) treated at $190{ }^{\circ} \mathrm{C}$, and P. brutia treated at temperatures exceeding $180{ }^{\circ} \mathrm{C}$

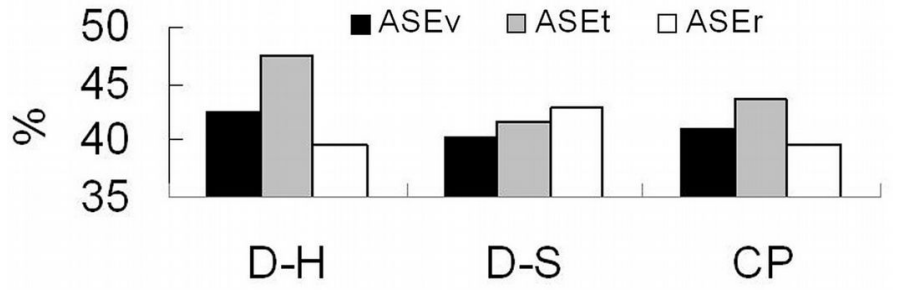

Fig. 3 - Antiswelling efficiency (ASE) coefficient, as measured in tangential $(A S E \mathrm{t})$ and radial (ASEr) directions with regard to volume (ASEv). 

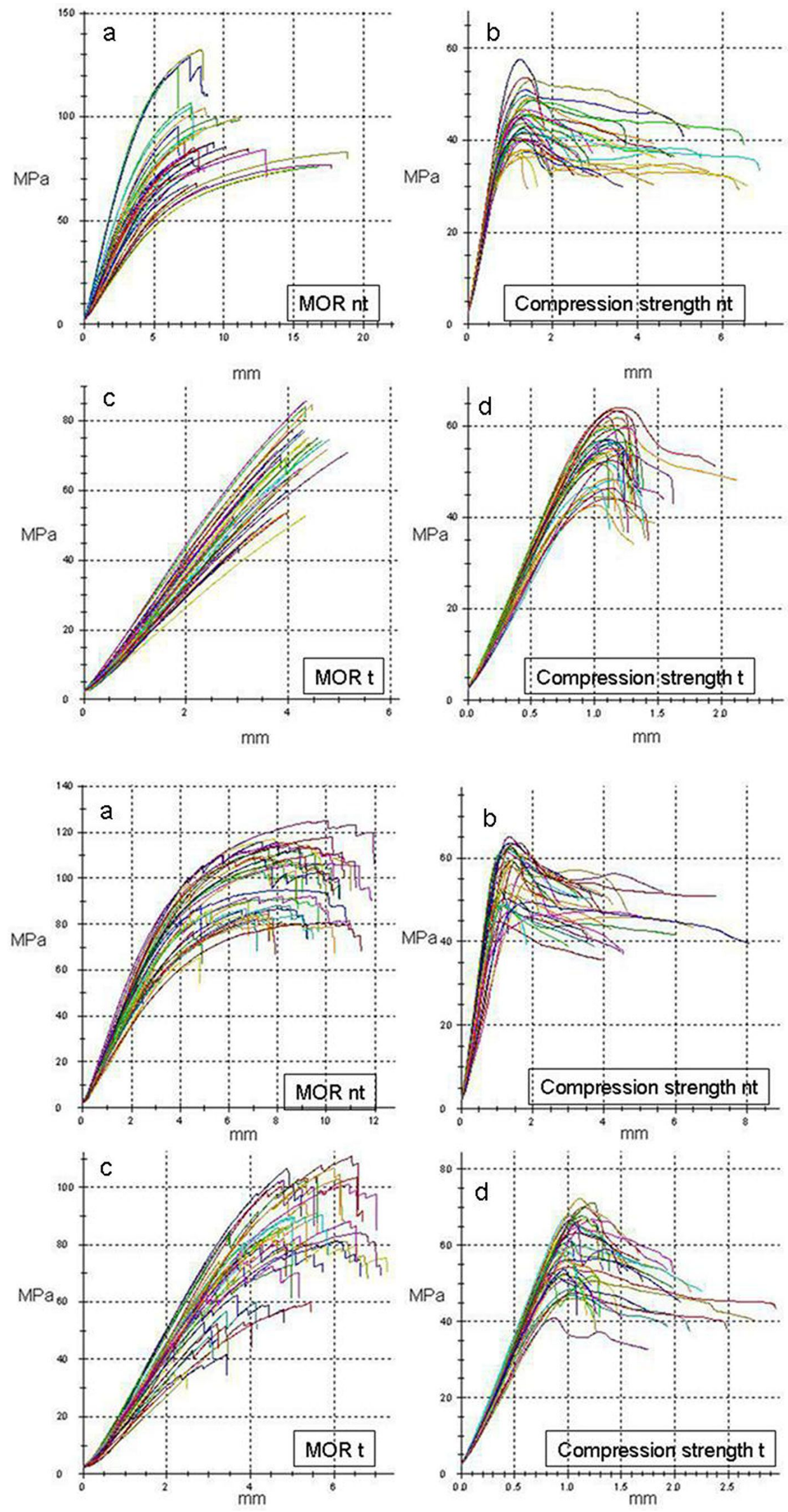

Fig. 4 - Load-deformation graph for Corsican pine showing the relationship between MOR $(a, c)$ and axial compression strength $(b, d)$ in treated $(t)$ and untreated specimens (nt).
Fig. 5 - Load-deformation graph for Douglas fir sapwood showing the relationship between MOR (a, c) and axial compression strength $(b, d)$ in treated $(t)$ and untreated specimens (nt). 
(Ates et al. 2009). As for Corsican pine, a behavior similar to Douglas fir heartwood was observed, though differences between treated and untreated samples were less evident. The Douglas fir examined in this study showed differences in hardness, an $8 \%$ reduction in sapwood, and a $28 \%$ significant decrease $(\mathrm{P}<0.05)$ in heartwood.

MOR value results showed a decrease of approximately $28 \%$ following heat treatment for both species, suggesting MOR was the most sensitive property to heat treatment. Several studies similarly reported decreased MOR in softwood and hardwood species (Repellin \& Guyonnet 2003, Leijten 2004, Esteves \& Pereira 2008, Ates et al. 2009, Srinivas \& Pandey 2012). Bal (2014) demonstrated the modification in bending strength (MOR) was due to mass loss following heat treatment, and although it was not possible to measure the mass loss in this experiment, some general comments can be made based on the knowledge that MOR typically exhibits a positive relationship to wood density (Zobel \& Van Buijtenen 1989, Nocetti et al. 2012, Romagnoli et al. 2014). In the present study, the density reduction following heat treatment was not as high as expected, particularly when compared to the observed change in strength. However, the ratio between the mechanical properties and untreated wood density would be expected to change following heat treatment due to chemical degradation of woody components, such as hemicelluloses and cellulose, which play a major role in determining wood properties in relationship to density (Esteves \& Pereira 2008). Furthermore, Corsican pine sapwood $\left(516.8 \mathrm{~kg} \mathrm{~m}^{-3}\right)$ had a higher density than Douglas fir $\left(457.3 \mathrm{~kg} \mathrm{~m}^{-3}\right)$, therefore a major decrease in Corsican pine sapwood mechanical properties after heat treatment should have been observed due to higher thermal conductivity of denser wood (Bal 2013, 2014). The differences detected might be explained by the volatile resin amounts in the two species' sapwood.

Lower mechanical performance in compression strength is usually found in heat treated hardwoods and softwoods (Ates et al. 2009, Korkut 2012). In our study, we observed a significant reduction $(\mathrm{P}<0.05)$ in axial compression strength in Douglas fir after heat treatment in both heartwood and sapwood. Corsican pine however, showed significantly higher axial compression strength $(4 \%, \mathrm{P}<0.05)$ in the treated samples. This is reflected in the Corsican pine bending MOE values, which were also higher in treated samples $(12 \%)$ and were consistent with other studies (Santos 2000, Boonstra et al. 2007, Bal 2014).

Results showed the reduction in mechanical properties due to heat treatment was in some cases lower than that observed in $\mathrm{Pi}$ nus banksiana (Kocaefe et al. 2010) and in a

Density - Radial shrinkage

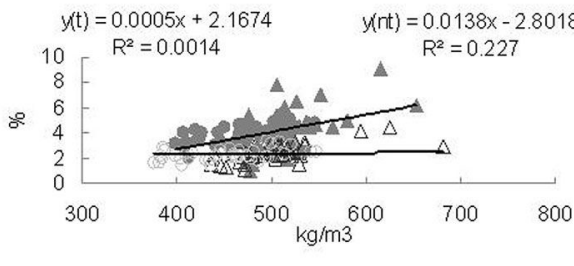

$\triangle \mathrm{CP} n \mathrm{CPt} \bullet \mathrm{Dnt} \triangle \mathrm{Dt}$

C Density - Anisotropy coefficient $y(t)=0.0003 x+1.6292 \quad y(n t)=-0.0017 x+2.6977$ $\begin{array}{cc}y(t)=0.0003 x+1.6292 & Y(n t)=-0.0017 x+2.6977 \\ R^{2}=0.0011 & R^{2}=0.0247\end{array}$

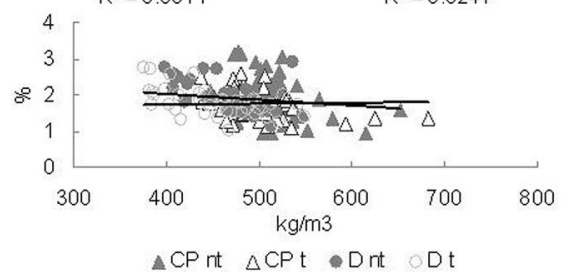

$\triangle \mathrm{CP} n \mathrm{CP} \mathrm{CP} \in \mathrm{Dnt} D \mathrm{Dt}$ b Density - Tangential shrinkage

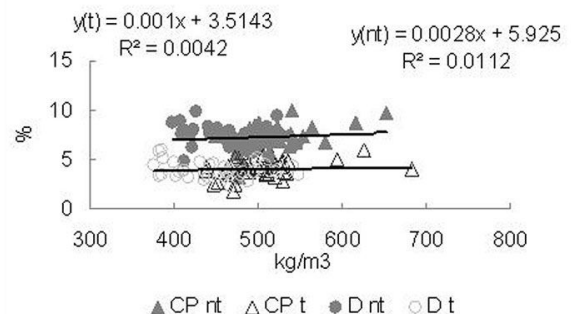

d Density - Volumetric shrinkage

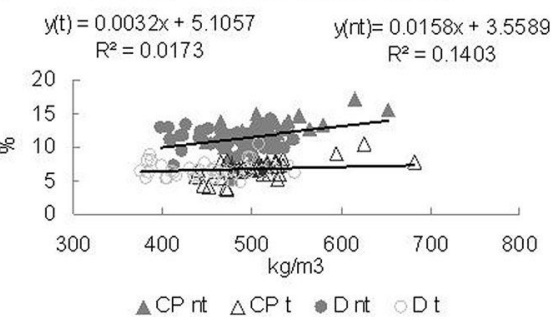

Fig. 6 - Linear regression between density and the measured physical properties in treated (t) and untreated (nt) specimens for Corsican pine (CP) and Douglas fir (D).
P. nigra (Gunduz et al. 2008, Bal 2014). In our study, the bending MOE was not notably affected by heat treatment in Corsican pine or Douglas fir, particularly when compared with results reported in hardwoods, including aspen (Tremblay \& Baribeault 2009) and birch (Shi et al. 2007).

Special attention must be given to the loaddeflection curves (Fig. 4, Fig. 5) when assessing MOR and axial compression strength. Heat-treated Corsican pine exhibited abrupt failures in MOR values when it reached a deformation of approximately $4 \mathrm{~mm}$, and a considerably larger deflection at maximum load for untreated samples. The curve shape typically reflects the behavior of heat-treated wood, which was reported in other wood

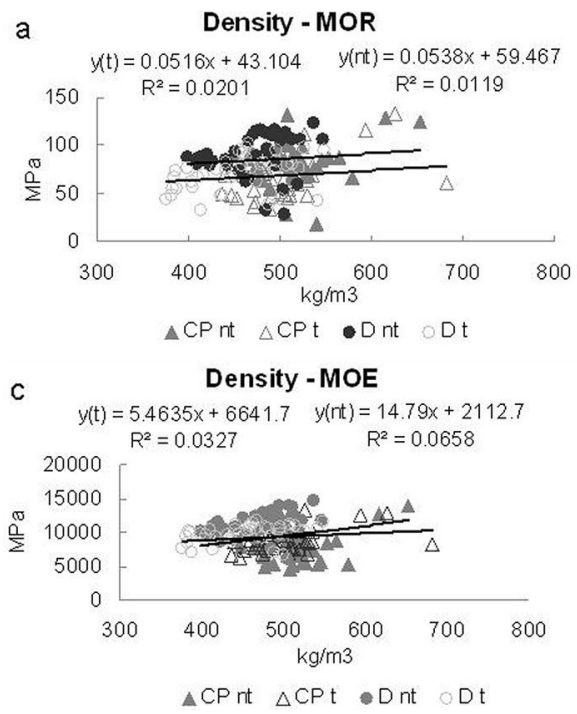

species (Arnold 2010) and ascribed to transverse fracture surfaces of tension-stressed fibers, or transverse ruptures in tracheid cell walls (Arnold 2010). Unsal \& Ayrilmis (2005) showed compression strength was reduced by heat treatment, even under relatively low temperature conditions. Many Corsican pine control samples under compression exhibited a residual deformation up to $6 \mathrm{~mm}$ (Fig. $4 \mathrm{~b}$ ) after reaching maximum load, whereas the mechanical behavior demonstrated by the load-deformation graph differed in Douglas fir (Fig. 5b). Specifically, the MOR value following the maximum load shows a residual deformation lower than that observed in control (nt) samples (Fig. 5a, Fig. 5c), with the same result ob-
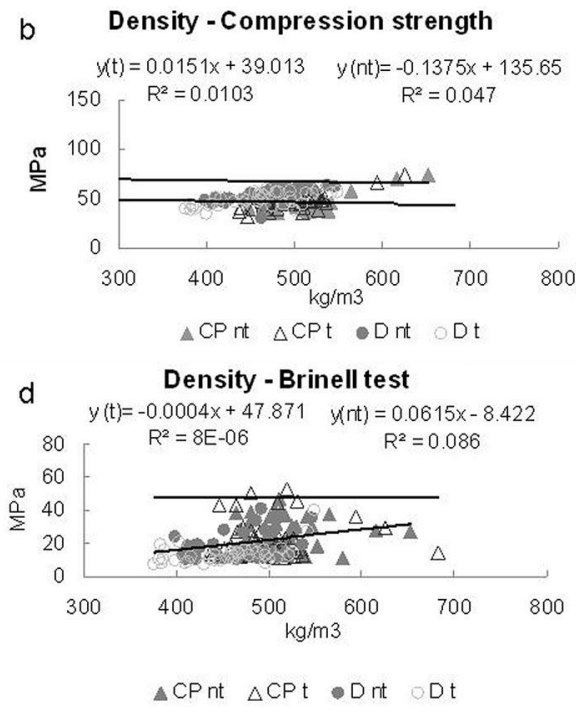

Fig. 7 - Linear regression between wood density and mechanical properties in treated (t) and untreated (nt) samples for Douglas fir. The Douglas fir sapwood and heartwood specimens were grouped together. (MOR): bending strength; (MOE): bending modulus of elasticity. 
Tab. 2 - Pearson's correlation analysis between density and physical-mechanical properties. (MOR): bending strength; ( $\sigma c)$ : axial compression strength; (HB): Brinell hardness; (MOE): bending modulus of elasticity; $\left(\beta_{\mathrm{V}}\right)$ : volumetric shrinkage; $\left(\beta_{\mathrm{r}}\right)$ : radial shrinkage; $\left(\beta_{\mathrm{t}}\right)$ : tangential shrinkage; $(\Psi)$ : coefficient of anisotropy; (CP): Corsican pine; (D-S): Douglas fir sapwood; (D-H): Douglas fir heartwood, (nt): un treated; $(\mathrm{t})$ : treated. $(*),(* *),(* * *)$ : levels of significance between treated $(\mathrm{t})$ and untreated $(\mathrm{nt})$ specimens at $\mathrm{P}<0.05, \mathrm{P}<0.01$, and $\mathrm{P}<$ 0.001 , respectively using the Bonferroni's test.

\begin{tabular}{|c|c|c|c|c|c|c|c|c|}
\hline Parameter & $\begin{array}{l}\text { MOR } \\
\text { (MPa) }\end{array}$ & $\begin{array}{c}\sigma_{12} \\
(\mathrm{MPa})\end{array}$ & $\begin{array}{c}\text { HB } \\
(\mathrm{MPa})\end{array}$ & $\begin{array}{l}\text { MOE } \\
\text { (MPa) }\end{array}$ & $\begin{array}{c}\beta_{V} \max \\
(\%)\end{array}$ & $\begin{array}{c}\beta_{\mathrm{r}} \max \\
(\%)\end{array}$ & $\begin{array}{c}\boldsymbol{\beta}_{\mathrm{t}} \max \\
(\%)\end{array}$ & $\Psi$ \\
\hline CP nt $(n=40)$ & 0.385 & $0.767 * * *$ & 0.135 & $0.468^{*}$ & $0.610^{* * *}$ & $0.554^{* *}$ & $0.487 *$ & -0.381 \\
\hline $\mathrm{CP} t(\mathrm{n}=40)$ & $0.636 * * *$ & $0.695 * * *$ & 0.127 & $0.358 * * *$ & $0.630^{* * *}$ & $0.726 * * *$ & 0.441 & -0.392 \\
\hline $\mathrm{D}-\mathrm{S}$ nt $(\mathrm{n}=12)$ & 0.231 & $0.643 * * *$ & 0.353 & 0.416 & -0.143 & 0.400 & -0.540 & $-0.885 * * *$ \\
\hline $\mathrm{D}-\mathrm{S} \mathrm{t}(\mathrm{n}=12)$ & 0.274 & $0.603 * *$ & 0.264 & 0.460 & -0.347 & 0.358 & -0.649 & -0.681 \\
\hline D-H nt $(n=28)$ & 0.152 & $0.418^{* *}$ & 0.209 & 0.228 & 0.190 & 0.331 & 0.032 & -0.344 \\
\hline $\mathrm{D}-\mathrm{H} \mathrm{t}(\mathrm{n}=28)$ & 0.245 & 0.284 & 0.365 & 0.150 & 0.236 & 0.356 & 0.143 & -0.390 \\
\hline
\end{tabular}

served in compression strength.

Sapwood and heartwood results before and after treatment requires special consideration. For example, heat treatment appeared to mitigate the differences between the two tissues (heartwood and sapwood) compared to the physical and mechanical properties of non-treated wood material, with the exception of the compression strength (Cao et al. 2012). Heat treatment also affected heartwood specific density and volumetric shrinkage; however, bending MOE, compression strength, and hardness was primarily impacted in sapwood. It was notable that bending strength and MOE decrease in sapwood was observed, but a significant reduction was not detected. This result indicated it is possible to obtain an improvement in dimensional stability in Douglas fir sapwood, with a far less substantial loss of mechanical performance than would otherwise be expected.

Few studies have evaluated the different behaviors of sapwood and heartwood after thermowood treatment. A recent paper examined EMC in Turkey oak (Todaro et al. 2012), however the outcome of this and other studies were not congruent with our results. In fact, Burgos \& Rolleri (2012) observed increased shrinkage in heat-treated Douglas fir wood, with decreased extractives, although the result might be comparable, as Douglas fir sapwood contains fewer extractives than heartwood. A separate examination of radial and tangential directions in the present study indicated $A S E$ was very similar to shrinkage values, with the exception of heartwood vs. sapwood radial shrinkage. Sapwood substances might be chemically modified into new polyphenols, which could affect the expected physical and mechanical behavior of sapwood (Alen et al. 2002). A linear regression analysis was performed between density and shrinkage for Corsican pine and Douglas fir, and results showed that both species exhibited very low $R^{2}$ values (Fig. 6, Fig. 7). It can be hypothesized that the absence of a relationship between the variables could be due to juvenile wood in the conifer tissue, which weakened the mechanical properties as compared with mature wood. Increased shrinkage can be explained by orientation of the microfibril angle; and decreased wood density did not make as great a contribution (Zobel \& Sprague 1998, Larson et al. 2001, Bal 2014). Following treatment, density did not exhibit an increased relationship to physical properties (Fig. 6), and its relationship to mechanical properties was reduced (Fig. 7). Increased understanding can be inferred from the correlation coefficient between density and the physical and mechanical properties (Tab. 2 ), where the correlation was often significant in Corsican pine. However, Douglas fir showed an absence of significant results, with the exception of sapwood density-compression strength and density-anisotropy coefficients. In addition, a remarkable result showed the correlation coefficient between density, MOR, and radial shrinkage was increased by heat treatment.

The most marked result, however, was the change in the correlation trend between density and radial shrinkage after heat treatment. The hornification process might serve to explain this result, which in spruce promoted irreversible hydrogen bonding between wood elements during drying that accompanied heat treatment (Borrega \& Kärenlampi 2010a). Hornification is a process term often applied to wood pulp when polymeric structures in lignocellulosic materials stiffen during drying (Fernandes Diniz et al. 2004). Hornification in heat-treated wood results in a mass reduction without decreasing mechanical properties, and in spruce studies demonstrated increased MOR and MOE up to a $3 \%$ mass loss, depending on the relative humidity of the drying process (Borrega \& Kärenlampi 2008, 2010a, 2010b). Although mass loss could not be determined in our experiment, based on the slight decrease in Corsican Pine density $(\approx 2 \%)$, we speculated it was at least within the range determined by Borrega \& Kärenlampi (2008).

In untreated samples, density was strongly related to MOR and compression strength. In comparison, heat treatment did not substantially effect the correlation between density and MOE, which can be explained by the hornification mechanism, which in spruce dominated the influence of mass loss on strength and stiffness (Borrega \& Kärenlampi 2010a). Epmeier \& Kliger (2005) previously demonstrated the correlation between bending MOE and density in $P$. sylvestris was significant in raw material, but was lost following wood modification, a characteristic also observed in Cedrus libani sapwood (Bal 2013). This was confirmed in our Corsican pine sapwood, and can be considered an advantage because such mass loss does not have a pronounced effect on mechanical strength.

Density impacted compression strength in untreated Douglas fir sapwood and heartwood specimens. Following treatment, the correlation was maintained and significant compression strength results were revealed, but values were reduced. In Corsican pine sapwood, heat treatment reduced the density and MOR/MOE correlation. It also decreased the effect on shrinkage values, although the results remained significant.

\section{Conclusion}

Corsican pine heat treatment significantly reduced the anisotropy coefficient and shrinkage, whereas in Douglas fir sapwood specific density was most impacted by heat treatment. Overall, $P$. nigra subsp. laricio results suggested this material has more potential as a valuable wood product than biomass for energy or to manufacture pallets, which indicates silvicultural options should be explored. Treatment had a decreased effect on wood density and subsequent physical and mechanical properties, which could promote silviculture with high growth rates. In fact, even with a wider ring width and increased amount of earlywood, and therefore lower density, the reduction does not noticeably compromise the physical and mechanical characteristics of the treated wood. Douglas fir results indicated heat treatment was notably less beneficial in terms of mechanical performance. Furthermore, this species has naturally good wood durability, and the increased heartwood presence was reported to be associated with high growth rates. These 
characteristics therefore discourage further investment into P. menziesii heat processing, as treatment is only required if the need is evident for more dimensional stabilization in specific wood products.

\section{References}

Alen R, Kotilainen R, Zaman A (2002). Thermochemical behaviour of Norway Spruce (Picea abies) at $180-225{ }^{\circ} \mathrm{C}$. Wood Science and Technology 36 (2): 163-171. - doi: 10.1007/s00226001-0133-1

Arnold M (2010). Effect of moisture on the bending properties of thermally modified beech and spruce. Journal of Material Science 45 (3): 669680. - doi: 10.1007/s10853-009-3984-8

Ates S, Akyildiz MH, Ozdemir H (2009). Effects of heat treatment on Calabrian pine (Pinus brutia Ten.) wood. BioResources 4 (3): 1032-1043. [online] URL: https://ojs.cnr.ncsu.edu/index.ph p/BioRes/article/view/BioRes_04_3_1032_Ates AO Heat Treat Calabrian_Pine

Bakar BFA, Hiziroglu S, Tahir PM (2013). Properties of some thermally modified wood species. Materials and Design 43: 348-355. - doi: 10.1016/j.matdes.2012.06.054

Bal BC (2013). Effetcs of hest treatment on the physical properties of heartwood and sapwood of Cedrus libani. Bioresources 8 (1): 211-219. doi: 10.15376/biores.8.4.6493-6500

Bal BC (2014). Some physical and mechanical properties of thermally modified juvenile and mature black pine wood. European Journal of Wood Products 72 (1): 61-66. - doi: 10.1007/ s00107-013-0753-9

Bekhta P, Niemz P (2003). Effect of high temperature on the change in color, dimensional stability and mechanical properties of spruce wood. Holzforshung 57 (5): 539-546. - doi: 10.1515/ HF. 2003.080

Bengtsson C, Jermer J, Brem F (2002). Bending strength of heat-treated spruce and pine timber. In: Proceedings of the Conference "International Research Group Wood Pre". Cardiff (Wales, UK), 12-17 May 2002. Section 4 - Processes, no. IRG/WP 02-40242. [online] URL: http://www. irg-wp.com/irgdocs/details.php?cf905362-e47b4ce1-80ca-84c0287f2be7

Boonstra M, Van Acker J, Tjeerdsma B, Kegel E (2007). Strength properties of thermally modified softwoods and its relation to polymeric structural wood constituent. Annals of Forest Science 64 (7): 679-690. - doi: 10.1051/forest:20 07048

Borrega M, Kärenlampi PP (2008). Mechanical behaviour of heat-treated spurce (Picea abies Karst.) wood at constant moisture content and relative humidity. Holz als Roh und Werkstoff 66 (1): 63-69. - doi: 10.1007/s00107-007-0207-3 Borrega M, Kärenlampi PP (2010a). Hygroscopicity of heat-treated Norway spruce (Picea abies) wood. European Journal of Wood and Wood Products 68 (2): 233-235. - doi: 10.1007/s001 07-009-0371-8

Borrega M, Kärenlampi PP (2010b). Three mechanisms affecting the mechanical properties of spruce wood dried at high temperatures. Journal of Wood Science 56 (2): 87-94. - doi: 10.1007/ s10086-009-1076-7

Burgos F, Rolleri A (2012). Effect of hydro- and hygro-thermal treatments on some wood properties of Pinus radiata and Pseudotsuga menziesii. Drvina Industrija 63 (3): 211-215. - doi: 10.5552 /drind.2012.1133

Cao Y, Lu J, Huang R, Jiang J (2012). Increased dimensional stability of Chinese fir through steam-heat treatment. European Journal of Wood Products 70 (4): 441-444. - doi: 10.1007/s0010 7-011-0570-y

Epmeier H, Kliger R (2005). Experimental study of material properties of modified Scots pine. Holz als Roh und Werkstoff 63 (6): 430-436. doi: 10.1007/s00107-005-0019-2

Esteves B, Marques AV, Domingos I, Pereira H (2007a). Influence of steam heating on the properties of pine (Pinus pinaster) and eucalypt (Eucalyptus globulus) wood. Wood Science and Technology 41 (3): 193-207. - doi: 10.1007/s002 26-006-0099-0

Esteves B, Domingos I, Pereira H (2007b). Improvement of technological quality of eucalypt wood by heat treatment in air at $170-200{ }^{\circ} \mathrm{C}$. Forest Products Journal 57 (1-2): 47-52. [online] URL: http://repositorio.ipv.pt/handle/10400.19/1 076

Esteves BM, Pereira HM (2008). Wood modification by heat treatment: a review. BioResources 4 (1): 370-404. [online] URL: http://ojs.cnr.ncsu. edu/index.php/BioRes/article/view/BioRes_04_1 Esteves B, Velez Marques A, Domingos I, Pereira H (2008). Heat-induced color changes of pine (Pinus pinaster) and eucalypt (Eucalyptus globulus) wood. Wood Science and Technology 42 (5): 369-384. - doi: 10.1007/s00226-007-0157-2 Fernandes Diniz JMB, Gill MH, Castro JAAM (2004). Hornification - its origin and interpretation in wood pulps. Wood Science and Technology 37 (6): 489-494. - doi: 10.1007/s00226-003 -0216-2

Fioravanti M (1999). Valutazione tecnologica dell'influenza delle pratiche selvicolturali sulla qualità del legno [Technological evaluation of the silvicoltural practices on wood quality]. In: "Il Legno di Castagno e di Douglasia della Toscana - Qualità del legno e selvicoltura". Quaderno ARSIA 9/99, ARSIA Azienda Regionale per lo Sviluppo e l'innovazione nel Settore Agricoloforestale, Firenze, Italy, pp. 23-39. [in Italian]

González-Peña MM, Curling SF, Hale MDC (2009). On the effect of heat on the chemical composition and dimensions of thermally-modified wood. Polymer Degradation and Stability (94): 2184-2193. - doi: 10.1016/j.polymdegradst ab.2009.09.003

Gunduz G, Korkut S, Korkut DS (2008). The effects of heat treatment on physical and technological properties on surface roughness of Camiyani - Black Pine (Pinus nigra Arn. subsp. pallasiana var. pallasiana) wood. Bioresource Technology 99 (7): 2275-2280. - doi: 10.1016/j.bior tech.2007.05.015

Hillis CAS (2006). Wood modification. Chemical, thermal and other processes. John Wiley and Sons, Chichester, UK, pp. 260.

Johanson D, Moren T (2006). The potential of colour measurement for strength pprediction of thermally treated wood. Holz als Roh und Werkstoff 64 (2): 104-110. - doi: 10.1007/s00107-00 5-0082-8

Kandem DP, Pizzi A, Jermannaud A (2002). Durability of heat treated wood. Holz als Roh und Werkstoff 60 (1): 1-16. - doi: 10.1007/s00107001-0261-1

Kocaefe D, Poncsak S, Tang J, Bouzara M (2010). Effect of heat treatment on the mechanical properties of North America jack pine: thermogravimetric study. Journal of Materials Science 45 (3): 681-687. - doi: 10.1007/s10853-009-3985-7 Korkut S (2012). Performance of three thermally treated tropical wood species commonly used in Turkey. Industrial Crops and Products 36 (1) 355-362. - doi: 10.1016/j.indcrop.2011.10.004

Kortelainen SM, Antikairem T, Vitamieni P (2006). The water absorption of sapwood and heartwood of Scots pine and and Norway spruce heat-treated at $170{ }^{\circ} \mathrm{C}, 190{ }^{\circ} \mathrm{C}, 210{ }^{\circ} \mathrm{C}, 230^{\circ} \mathrm{C}$. Holz als Roh und Werkstoff 64 (2): 192-197. doi: 10.1007/s00107-005-0063-y

Lachenbruch B, Johnson JR, Downes GM, Evans R (2010). Relationships of density, microfibril angle, and sound velocity with stiffness strenght in mature wood of Douglas fir. Canadian Journal of Forest Research 40 (1): 55-64. - doi: 10.11 39/X09-174

Larson P, Kretschmann D, Clark A, Isebandsm JG (2001). Formation and properties of juvenile wood in southern pines. A synopsis. Gen. Tech. Rep. FPL-GTR-129, Forest Products Laboratory, USDA Forest Service, Madison, WI, USA, pp. 42.

Leijten AJM (2004). Heat treated wood and the influence on the impact bending strength. Heron (49): 349-359. [online] URL: http://heronjournal.nl/49-4/4.pdf

Li XJ, Cai JY, Mou QY, Wu YA, Liu Y (2011). Effects of heat treatment on some physical properties of Douglas fir (Pseudotsuga menziesii) wood. Advanced Materials Research 197: 90-95. - doi: 10.4028/www.scientific.net/AMR.197-198 .90

Metsä-Kortelainen S (2011). Difference between sapwood and heartwood of thermally modified Norway spruce (Picea abies) and Scots pine (Pinus sylvestris) under water and decay exposure. VTT publications 771: 1-58.

Militz H (2002). Heat treatment technologies in Europe: scientific background and technological state-of-art. In: Proceedings of the Conference "Enhancig the durability of lumber and engineered wood products". Kissimmee (Orlando, FL, USA) 11-13 Feb 2002. Forest Products Society, Madison, PA, USA, pp. 19.

Militz H (2008). Processes and properties of thermally modified wood manufactured in Europe. In: "Development of Commercial Wood Preservatives. Efficacy, Environmental and Health Issues" (Schultz TP, Militz H, Freeman M, Goodell B, Nicholas DD eds). ACS Symposium Se- 
ries, Oxford University Press, Oxford, UK, pp. 372-388. [online] URL: http://cat.inist.fr/?aModele $=$ afficheN\&cpsidt $=20261852$

Mohareb A, Sirmah P, Desharnais L, Dumarçay S, Pétrissans M, Gérardin P (2010). Effect of extractives on conferred and natural durability of Cupressus lusitanica heartwood. Annals of Forest Science 67 (5): 504-504. - doi: 10.1051/fo rest $/ 2010006$

Nardi Berti R (2006). La struttura anatomica del legno ed il riconoscimento dei legnami italiani di più corrente impiego [Anatomical structure of wood and identification of the most common used wood in Italy] $\left(2^{\text {nd }}\right.$ edn). Compagnia delle foreste, Firenze, Italy, pp 158. [in Italian]

Nocetti M, Brunetti M, Ducci F, Romagnoli M, Rozenberg P, Santi F (2012). Phenotypic correlations among wood properties and growth in wild cherry plantations. Bioresources 7 (3): 3160 3174. [online] URL: https://ojs.cnr.ncsu.edu/index.php/BioRes/article/view/BioRes_07_3_3160 Poncsak S, Kocaefe D, Younsi R (2011). Improvement of the heat treatment of Jack pine ( $P i-$ nus banksiana) using ThermoWood technology. European Journal of Wood Products 9 (2): 281286. - doi: 10.1007/s00107-010-0426-x

Repellin V, Guyonnet R (2003). Evaluation of heat treated beech by non-destructive testing. In: Proceedings of the "European Conference on Wood Modification". Gand (Belgium) 3-4 Apr 2003. HAL, archives-ouverted.fr, France, pp.11. [online] URL: http://hal.archives-ouvertes.fr/hal00123723/document

Romagnoli M, Spina S (2013). Physical and mechanical wood properties of ring-shaken chestnut (Castanea sativa) trees. Canadian Journal of Forest Research 43 (2): 200-207. - doi: 10.1139/cj fr-2012-0357

Romagnoli M, Cavalli D, Spina S (2014). Wood quality of chestnut: relationships between ring width, specific density and physical mechanical properties. Bioresources 9 (1): 1132-1147. - doi: 10.15376/biores.9.1.1132-1147

Santos JA (2000). Mechanical behavior of Eucalyptus wood modified by heat. Wood Science and Technology 34 (1): 39-43. - doi: 10.1007/ s002260050006

Severo ETD, Calonego FW, Sansigolo CA (2012).
Physical and chemical changes in juvenile and mature woods of Pinus elliottii var. elliottii by thermal modification. European Journal of Wood and Wood Products 70: 741-747. - doi: 10.1007/ s00107-012-0611-1

Shi JL, Kocaefe D, Zhang J (2007). Mechanical behaviour of Québec wood species heat-treated using thermowood process. Holz als Roh- und Werkstoff (65): 255-259. - doi: 10.1007/s00107007-0173-9

Srinivas K, Pandey KK (2012). Effect of heat treatment on color changes, dimensional stability, and mechanical properties of wood. Journal of Wood Chemistry and Technology (32): 304316. - doi: 10.1080/02773813.2012.674170

Stamm A, Burr H, Kline A (1946). Heat stabilized wood (Staybwood). Industrial and Engeneering Chemical Research 38 (6): 630-634. - doi: 10.1021/ie50438a027

Todaro L, Macchioni N (2011). Wood properties of young Douglas-fir in Southern Italy: results over a 12-year post-thinning period. European Journal of Forest Research 130 (2): 251-261. doi: 10.1007/s10342-010-0425-9

Todaro L, Zanuttini R, Scopa A, Moretti N (2012). Influence of combined hydro-thermal treatments on selected properties of Turkey oak (Quercus cerris L.) wood. Wood Science and Technology 46 (1-3): 563-578.

Tremblay C, Baribeault J (2009). Physical and mechanical properties of thermally modified aspen wood. In: Proceedings of the "European Conference on Wood Modification" (Englund F, Hill CAS, Militz H, Segerholm BK). Stockholm (Sweden) 27-29 Apr 2009, pp. 231-234.

UNI-EN-1534 (2011). Pavimentazioni di legno Determinazione della resistenza alla penetrazione - Metodo di prova [Wood flooring- determination of resistance to indentation - Test method]. Ente Italiano di Normazione, Milan, Italy. [in Italian]

UNI-ISO-3130 (1985). Legno. Determinazione del contenuto di umidità per le prove fisiche e meccaniche [Wood. Determination of moisture content for pyisical and mechanical tests]. Ente Nazionale Italiano di Normazione, Milan, Italy, pp. 3. [in Italian]

UNI-ISO-3131 (1985). Legno. Determinazione della massa volumica per le prove fisiche e meccaniche [Wood. Determination of density for physical and mechanical tests]. Ente Nazionale Italiano di Normazione, Milan, Italy, pp. 4. [in Italian]

UNI-ISO-3133 (1985). Determinazione della resistenza a flessione statica del legno [Determination of ultimate strength in static bending]. Ente Nazionale Italiano di Normazione, Milan, Italy, pp. 3. [in Italian]

UNI-ISO-3787 (1985). Legno. Metodi di prova. Determinazione della resistenza a compressione parallela alla fibratura [Wood. Test methods. Determination of ultimate stress in compression parallel to grain]. Ente Nazionale Italiano di Normazione, Milan, Italy. [in Italian]

Unsal O, Ayrilmis N (2005). Variations in compression strength and surface roughness of heattreated Turkish river red gum (Eucalyptus camaldulensis) wood. Journal of Wood Science 51 (4): 405-409. - doi: 10.1007/s10086-004-0655-x Welzbacher CR, Rapper A (2007). Durability of thermally modified timber from industrial-scale processes in different use classes. Results from laboratory and field test. Wood Material Science and Engineering 2 (1): 4-14. - doi: 10.1080/1748 0270701267504

Welzbacher CR, Brischke C, Rapp AO (2007). Influence of heat treatment temperature and duration on selected biological, mechanical, physical and optical properties od thermally modified timber. Wood Material Science Engineering 2 (2): 66-76. - doi: 10.1080/17480270701770606

Zaman A, Alen R, Kotilainen R (2000). Thermal behavior of Scots pine (Pinus sylvestris) and silver birch (Betula pendula) at 200-230 . Wood Fiber Science 32 (2): 138-143. [online] URL: http://swst.metapress.com/content/1854543q337 50374/

Zobel B, Sprague J (1998). Juvenile wood in forest trees. Springer Verlag, Berlin, Heidelberg, Germany, pp. 300

Zobel BJ, Van Buijtenen JP (1989). Wood variation: its causes and control. Springer Verlag Gmbh, Berlin, Heidelberg, Germany, pp. 363. [online] URL: http://www.cabdirect.org/abstracts /19910652155.html 